\title{
MicroscopyPioneers
}

\section{Pioneers in Optics: Henri Hureau de Sénarmont}

\section{Eric Clark}

From the website Molecular Expressions created by the late Michael Davidson and now maintained by Eric Clark, National Magnetic Field Laboratory, Florida State University, Tallahassee, FL 32306

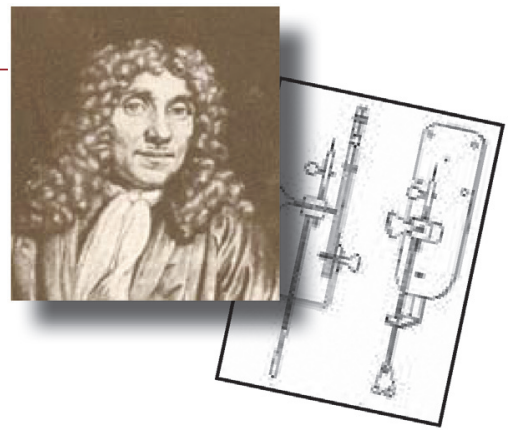

eclark@magnet.fsu.edu

\section{Henri Hureau de Sénarmont (1808-1862)}

Henri Hureau de Sénarmont was a renowned nineteenthcentury French mineralogist who became the engineer-in-chief of mines. He was a professor of mineralogy and director of studies at the École des Mines in Paris, especially distinguished for his research on polarization and his studies on the artificial formation of minerals. He also contributed to the Geological Survey of France by preparing geological maps and essays. Perhaps the most significant contribution made by de Sénarmont to optics was the polarized light retardation compensator bearing his name, which is still widely used today.

Sénarmont was born on September 6, 1808, the nephew of the famous French artillery general of the same name. His father was also in the service but married young and left the military to devote himself to his family and the education of his children. Sénarmont spent his early years at Dreux under the watchful eyes of his parents. In 1822, however, he left for Paris to continue his education and was accepted at the Polytechnic School, where he studied until 1826. He then attended and graduated from École des Mines at Paris. When he left in 1829, he enthusiastically began his career in the mining industry. He married in 1834 but was bereft of his wife only four years later. His first scientific publications were not released until 1839, after he was already widowed. Although de Sénarmont achieved much during his lifetime, his successful career was cut short when he died unexpectedly in Paris at the age of 53 on June $30,1862$.

In 1843, de Sénarmont began a project that he would work on for many years. He strongly criticized the mathematical theory of double refraction and began studies that would not be published until ten years later. His work at that time was closely involved with that of the famous physicist, Augustin Fresnel, whom he greatly admired. Sénarmont's predilections inspired him to concentrate on the preparation of a complete edition of Fresnel's works. The project was to be a monument to his eminent scientific predecessor. Although de Sénarmont was not able to finish the endeavor himself, the work was far enough advanced before his death that it could be completed by someone else.
During the 1850s, de Sénarmont became involved in the study of the optical properties of isomorphous bodies. He noticed that in certain minerals seemingly well defined, such as the micas, the axial spacing could greatly vary. The idea occurred to him that these substances were actually mixtures of minerals, which caused their optical properties to fluctuate. To confirm his belief, he began by preparing isomorphous salts that possessed a mixture of optical elements. He found that their simultaneous crystallization produced quite unexpected properties, which were useful in characterization. He then returned to the micas and demonstrated his theory through the examination of more than forty varieties of the mineral.

\section{de Sénarmont Compensator Configuration}

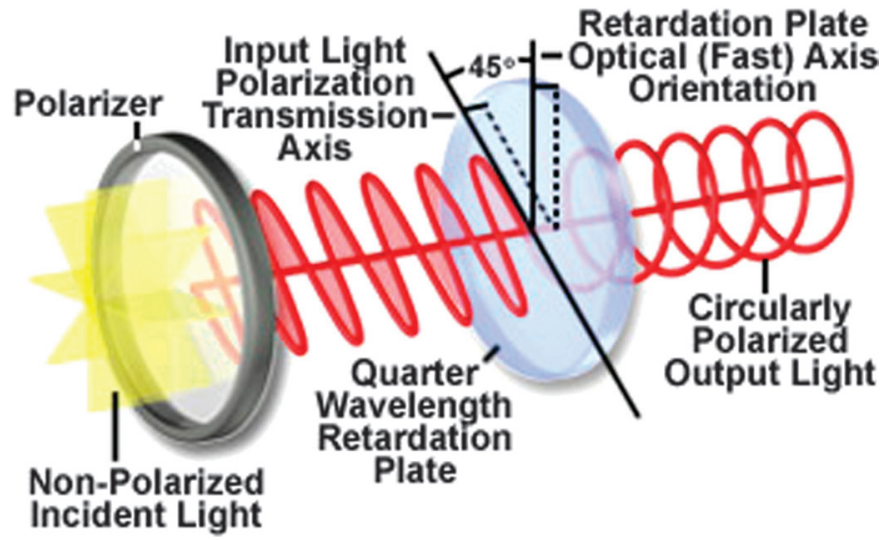

In 1851, de Sénarmont discovered a form of antimonic oxide that differs from ordinary oxidized antimony by its octahedral crystallization geometry. The species was named Sénarmontite in his honor. Around this same time, de Sénarmont was heavily involved in the study of one of his primary interests, the genesis of minerals. In 1852, his efforts were rewarded when he was offered the vacant seat in the Mineralogy section of the Academy of Science.

A device still in use today is the de Sénarmont compensator. It is composed of a linear polarizer combined with a quarterwavelength retardation plate and is capable of producing either linear, elliptical, or circularly polarized light, depending on the orientation of the polarizer vibration axis with respect to the fast and slow axes of the retardation plate. 


\section{June 2-7,}

2019

\section{LEHIGH}

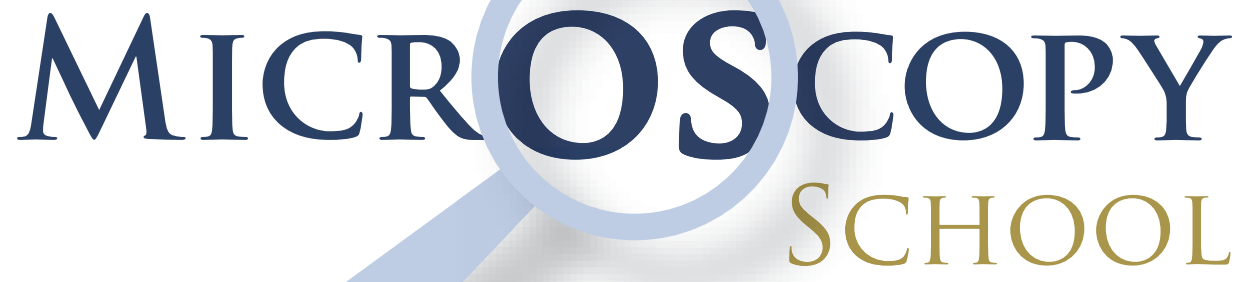

\section{Lehigh University, Bethlehem, PA USA}

\section{MAIN COURSES}

SCANNING ELECTRON MICROSCOPY AND X-RAY MICROANALYSIS

June 3-7

\section{SPECIALIZED COURSES}

FOCUSED ION BEAM (FIB): Instrumentation and Applications June 3-7

PROBLEM SOLVING:

Interpretation and Analysis of SEM/EDS/EBSD Data

June 3-7

For more information, contact:

Sharon Coe | 610.758.5133 | sharon.coe@lehigh.edu
INTRODUCTION TO SEM AND EDS FOR THE NEW OPERATOR June 2

QUANTITATIVE X-RAY

MICROANALYSIS:

Problem Solving using EDS and WDS Techniques

June 3-7

INTRODUCTION TO TEM June 2

TRANSMISSION

ELECTRON MICROSCOPY June 3-7 